\title{
Membangun kepedulian di masa covid-19 melalui program gerak sedekah millennial di Desa Tegalkamulyan Cilacap
}

\author{
Dewi Shantini Sari
}

Pendidikan Agama Islam, Fakultas Tarbiyah dan Ilmu Keguruan, IAIN Purw okerto

*Corresponding author, email: dewishantini693@gmail.com

$\begin{array}{ccc}\text { First received: } & \text { Revised: } & \text { Final Accepted: } \\ 26 \text { September } 2021 & 27 \text { Oktober 2021 } & \text { 28 Oktober 2021 }\end{array}$

\begin{abstract}
Abstrak
GerakSedekah Millennialmerupakan komunitas di bawahnaungan Lembaga Wakaf Al-Qur'an Cilacap (LWAC) yang lahir dari ide para remaja yang rutin dalam membantu menciptakan Lapak Sedekah sebagai kegiatan yang fokus pada gerakan sosial. Lapak Sedekah ini memberikan kesempatan bagi masyarakat yang ingin berpartisipasi sebagai donatur maupun sebagai penerima donasi. Donasi berupa al-Qur'an, sembako, pakaian, makanan siap konsumsi, bahan makanan, alat tulis, dan lain sebagainya. Tujuan pengabdian ini adalah membangun kepedulian kepada sesama di masa Covid- 19 melalui program gerak sedekah millennial. Metode yang digunakan adalah sosialisasi dan penyuluhan kepada remaja dan masyarakat melalui tatap muka ataupun media sosial seperti Facebook, Instagram, dan Whats App. Hasil pengabdian ini dapat menumbuhkan kepedulian remaja dalam kegiatan lapak sedekah. Kepedulian itu terlihat dari antusias para remaja yang bergabung kegiatan, serta antusias masyarakat yang berdonasi telah mampu menyukseskan kegiatan lapak sedekah. Kegiatan lapak sedekah ini mampu membangun kepedulian di masa Covid-19.
\end{abstract}

Kata Kunci: Kepedulian, Program Gerak Sedekah, Millennial, Komunitas

\begin{abstract}
The Millennial Alms Movement is a community under the auspices of the Cilacap AlQur'an Waqf Institute (LWAC) which was born from the idea of teenagers who routinely follow and help create Alms as an activity that focuses on social movements. This alms provides an opportunity for people who want to participate both as donors and as recipients of donations. Donations in the form of the Koran, basic necessities, clothing, ready-to-eat food, groceries, stationery, and so on. The purpose of this service is to build concern for others during the Covid-19 period through the millennial alms movement program. The method used is socialization and counseling to teenagers and the community through face-to-face or social media such as Facebook, Instagram, and Whats App. The results of this service can fosteryouth awareness in alms stall activities. This concern can be seen from the enthusiasm of the youth who join the activity, as well as the enthusiasm of the people who donate to be able to make the alms stall activity a success. This alms stall activity is able to build awareness during the Covid-19 period. Keyw ords: Concern, Alms Movement Program, Millennial, Community
\end{abstract}




\section{PENDAHULUAN}

Saat ini dunia sedang digemparkan dengan adanya wabah pandemi Covid-19. Covid-19 merupakan virus yang diduga berasal dari pasar hewan Huanan di Wuhan China, yang menjual berbagai jenis daging hewan eksotis, yang dianggap tidak layak konsumsi seperti kelelawar, tikus, ular dan lain sebagainya (Nurul Hidayah, dkk. 2021: 108). Saat ini, virus Covid-19 telah menyebar di 221 Negara di dunia termasuk Indonesia. Bahkan Indonesia masuk peringkat ke-13 kasus terbanyak di dunia (Worldometers. 2021). Hal ini membawa dampak bagi sebagian negara termasuk Indonesia. Seluruh masyarakat harus siap atas perubahan aktifitas sosial, dan segala kebijakan yang disusun sedemikian rupa oleh pemerintah. Tentunya segala perubahan kebijakan sementara oleh pemerintah bertujuan untuk pemutusan rantai penyebaran virus tersebut (Salasiah dkk., 2020: 160161). Mulai dari kebijakan Lockdown, Social Distancing, New Normal, Pembatasan Sosial Berskala Besar (PSBB), sampai Pemberlakuan Pembatasan Kegiatan Masyarakat (PPKM) yang berlevel I bahkan sampai IV. Penerapan protokol kesehatan seperti memakai masker, cuci tangan menggunakan sabun, penggunaan masker menjadi himbauan wajib bagi seluruh lapisan masyarakat.

Apabila suatu kondisi sosial primer berubah dalam masyarakat, maka berakibat adanya perubahan terhadap yang lain (Soerjon o Soekanto, 2000: 338). Melihat segala kebijakan tersebut, tentunya merubah sebagian kebiasaan masyarakat, baik dari aktivitas sosial, belajar, bekerja dan lain sebagainya. Masyarakat mau tidak mau harus beradaptasi dengan normal baru yang telah diterapkan. Mulai dari berdiam di rumah jika tidak ada kepentingan mendesak, menjaga jarak, sekolah dari rumah, bahkan pengurangan aktivitas bekerja. Tentunya hal ini sedikit banyak berdampak negatif bagi sebagian masyarakat dengan terganggunya aktivitas pendidikan, aktivitas bekerja, hingga sektor pariwisata.

Pemberlakuan belajar dan bekerja secara online menjadi pilihan yang dirasa tepat guna menangani penurunan angka kasus pandemi. Namun tentunya membawa kendala dan masalah yang cukup serius. Dimana mampu tidak mampu mereka dituntut memiliki alat penunjang minimal seperti smartphone baik bagi pelajar maupun pekerja. Bagi pelajar mereka harus siap mengimbangi waktu belajarnya di rumah sebagaimana belajar di sekolah. Kendala lain bagi sebagian pelajar adalah ketidakpunyaan smartphone yang digunakan untuk belajar online sehingga harus barengan dengan orangtuanya. Bahkan masalah lain yang muncul adalah mereka mulai jenuh yang berujung malas-malasan karena waktu yang sudah cukup lama (Afip Miftahul Basar, 2021: 212). Bagi pekerja masalah yang dihadapi antara lain kesulitan berkoordinasi dengan rekan karna terbiasa dengan suasana kerja konvensional, penjadwalan yang kurang rapi, waktu kerja yang cenderung tanpa batasan (Oswar Mungkasa, 2020: 131). Selain itu, perubahan mata pencaharian pada masyarakat, memberikan dampak pada perubahan pendapatan (Indraddin dan Irwan, 2016: 46).

Banyaknya kerugian yang disebabkan adanya pandemi, berdampak pada perekonomian masyarakat. Himbauan "stay at home" dari pemerintah yang mengakibatkan penurunan penghasilan masyarakat, terbatasnya aktivitas ekonomi, 
penutupan arena wisata, pengurangan gaji karyawan, pemutusan hubungan kerja (PHK), hingga usaha yang terpaksa harus gulung tikar (Zulkipli dan Muharir, 2021: 9-10). Tentunya segala kebijakan tersebut menjadi boomerang bagi pemerintah. Bagaimana pemerintah harus mengatasi permasalahan ekonomi yang mencekal sebagian masyarakatnya. Selain itu, melihat mirisnya dikalangan masyarakat khususnya para remaja, kemerosotan moral menjadi permasalahan yang serius di masa sekarang ini. Penyebab utamanya adalah penggunaan smartphone yang berlebih hingga acuh dan abai terhadap kehidupan realita disekitar. Mereka cenderung hidup dengan individualistik, hampir sebagiannya tertuju pada kotak logam yang digenggamannya (Inta Elok Youharti dan Hidayah, 2018: 148-149). Namun dapat diakui bahwa dengan melihat permasalahan di atas, perkembangan era digital smartphone tentunya tidak melulu memberikan dampak negatif. Di masa pandemi ini, berkembangnya teknologi tentunya memberikan efek positif bagi sebagian bidang agar tetap bergerak secara maksimal antara lain dalam bidang pendidikan dan usaha dagang secara online.

Melihat permasalahan-permasalahan di atas, mengenai lunturnya kepedulian sosial pada generasi milenial serta permasalahan ekonomi yang kian merajalela dikalangan masyarakat. Menjadi gagasan awal terbentuknya suatu komunitas di kalangan remaja di Desa Tegalkamulyan tepatnya Perumahan Tegal Asri guna memperbaiki dua masalah di atas. Komunitas tersebut dinamai Gerak Sedekah Milenial. Komunitas ini lahir atas ide para kumpulan remaja yang ikut khawatir dengan permasalahan yang terjadi di lingkungannya. Para remaja ini merupakan tentor mengaji yang rutin mengikuti dan membantu di Madrasah Diniah Nur Rohim perumahan Tegal Asri. Mereka turut prihatin melihat beberapa wali santri nya yang turut terkena dampak kebijakan pemerintah di masa pandemi ini. Selain itu, mereka turut miris melihat anak-anak dan remaja lain yang kian abai pada keadaan sekitar dan hanya sibuk dengan kotak logam yang mereka genggam. Didampingi oleh Ustadzah Lilik Barkun Jamilah selaku pengasuh Madrasah Diniah dan penasihat, perbincangan mengenai masalah wali santri dan beberapa warga sekitar, serta miris nya generasi millennial yang acuh terhadap keadaan sekitar, memberikan titik temu terbentuknya komunitas ini. Untuk itu, komunitas Gerak Sedekah Millennial bertujuan untuk membantu permasalahan-permasalahan yang terjadi di masyarakat yang fokus pada permasalahan ekonomi, serta membangun kepedulian pada sesama di masa sulit pandemi Covid-19, maupun setelah masa tersebut.

Komunitas merupakan sekumpulan manusia yang saling peduli terhadap manusia lain, dan memiliki hobi atau kebiasaan, minat dan nilai atau tujuan yang sama (Hermawan: 2008). Komunitas ini telah melahirkan gerakan yang fokus pada bidang sosial yang diberi nama Lapak Sedekah. Gerakan sosial ini dirasa tepat menjadi wadah dan sarana guna mewujudkan tujuan komunitas yakni untuk membangun kepedulian pada sesama. Dengan ini, upaya penanganan permasalahan ekonomi masyarakat diharapkan dapat sedikit terbantu. Baik bagi mereka yang ingin membagikan bantuannya, maupun bagi mereka yang membutuhkan uluran bantuan. Kepentingan yang sama antara sebagian masyarakat dan komunitas guna mengatasi kesejahteraan sosial dengan aksi peduli sesama, menjadi hal yang layak booming dikalangan masyarakat era teknologi ini. Selain itu gerakan sosial ini juga menjadi tombak awal untuk mengajak 
dan mengedukasi para remaja sekitar untuk melihat realita serta membantu warga sekitar serta memberikan kegiatan positif lainnya.

Sebagai makhluk sosial, manusia sangat perlu menanamkan rasa peduli sesama. Peduli sosial merupakan perbuatan dan sikap yang menggambarkan kepedulian terhadap manusia lain yang membutuhkan kebaikan, kerendahan hati, keramahan, dan lain sebagainya (M. Aulia Setiawan, dkk, 2017: 89). Membangun sikap peduli merupakan hal yang urgent dilakukan sedini mungkin agar menjadi generasi yang memiliki jati diri dari nilai-nilai baik dalam dirinya. Sehingga dapat membentuk generasi yang peka terhadap kehidupan disekitar dengan segala sikap dan tindakannya yang selalu meniatkan untuk memberi bantuan dan perdamaian. Tentunya nilai-nilai tersebut didapatkan melalui lingkungannya. Salah satu bagian penting dalam kehidupan guna memenuhi kebutuhan hidup adalah lingkungan, karena lingkungan yang baik akan melahirkan generasi yang baik pula (Rahayu Effendi, dkk. 2018:75)

Agar gerakan sosial ini semakin eksis dikalangan masyarakat, komunitas telah mengemas kegiatan ini secara modern dengan memanfaatkan teknologi digital seperti media sosial yang ada. Cara ini dinilai efektif guna membangun kepedulian sesama melihat kebiasaan mereka yang cenderung men-scroll media sosialnya. Pembuatan akun komunitas di Facebook dan Instagram menjadi alat pengenalan, sosialisasi, penyuluhan serta sebagai sarana ajakan bagi para viewers. Pengunggahan pamflet kegiatan di akun media sosial komunitas dan akun pribadi anggota menjadi alat penyebaran utama bagi seluruh masyarakat baik dalam menarik perhatian para donatur maupun penerima donasi. Pamflet tersebut diedit se menarik dan se kreatif mungkin agar dapat mengundang perhatian orang banyak. Kegiatan dapat memberikan informasi yang dapat melahirkan empati remaja yang melahirkan kepedulian kepada sesama (Marimbun, 2021)

Komunitas Gerak Sedekah Milenial diterima dengan sangat baik oleh warga Desa Tegalkamulyan khususnya perumahan Tegal Asri karena dinilai ikut berperan membangun kepedulian guna meningkatkan kesejahteraan sesama bagi masyarakat Tegal Asri. Selain itu pula sebagai sarana menumbuhkan dan memupuk kembali rasa peduli kepada generasi muda yang dianggap mulai luntur. Komunitas ini tentunya akan terus terbuka dan mengajak bagi para generasi muda untuk turut bergabung dan mewujudkan tujuan komunitas bersama-sama. Tentunya komunitas ini akan menerima dengan sangat baik ide dan kreativitas para anggota dan generasi muda untuk samasama menggapai tujuan komunitas guna membangun sikap berbagi terhadap sesama dengan cara mereka sendiri. Dengan harapan komunitas ini terus eksis, berkembang dan meluas bahkan hingga ke luar Desa Tegalkamulyan, dan dapat memberikan suatu yang bernilai positif bagi seluruh masyarakat. Selain itu, kegiatan Lapak Sedekah ini dinilai banyak membantu masyarakat sekitar guna memenuhi kebutuhan sehariannya dengan donasi yang mereka dapatkan. Permasalahan ekonomi yang mereka sedang mereka hadapi, sedikit banyak terbantu dengan Lapak Sedekah ini.

\section{METODE}

Metode yang digunakan adalah sosialisasi dan penyuluhan ke berbagai pihak guna membantu menyukseskan kegiatan yang diadakan oleh komunitas Gerak Sedekah 
Millennial dalam menyelesaikan persoalan dan masalah masyarakat. Sosialisasi dan penyuluhan dilakukan kepada para remaja sekitar untuk turut bergabung menjadi anggota dalam kegiatan ini, selain itu juga kepada masyarakat luas baik melalui langsung maupun melalui media sosial. Media sosial tersebut seperti Facebook, Instagram dan Whats App menjadi pusat sosialisasi dan penyuluhan yakni dengan mengunggah pamflet yang berisi edukasi, ajakan, dan tujuan kegiatan. Metode ini dilakukan guna menarik perhatian masyarakat baik sebagai donatur maupun penerima donasi. Tentunya para pemuda memegang peran penting dalam pelaksanaan kegiatan ini. Dalam pelaksanaan kegiatan ini terdapat tiga tahapan yakni tahapan persiapan, tahapan pelaksanaan dan tahap evaluasi. Penyuluhan dan sosialisasi dapat memberikan pemahaman kepada remaja terkait dengan tujuan pengabdian (Adelia, dkk, 2021; Triyana, dkk, 2021)

Sebagai langkah awal, Komunitas Gerak Sedekah Milenial memfokuskan pada permasalahan yang terjadi akibat dari dampak pandemi Covid-19. Permasalahan yang terjadi di desa Tegalkamulyan khususnya perumahan Tegal Asri adalah permasalahan ekonomi sebagai salah satu dampak kebijakan pemerintah dengan adanya PPKM. Dengan melihat situasi tersebut, munculah ide baru yakni dengan menciptakan Lapak Sedekah. Gerakan Lapak Sedekah bergerak dibidang sosial dengan sasaran seluruh masyarakat desa Tegalkamulyan. Gerakan ini menjadi wadah penerima donasi yang nantinya akan dibagikan kepada masyarakat yang membutuhkan. Dengan begitu, gerakan ini membutuhkan partisipasi masyarakat baik sebagai donatur maupun sebagai penerima donasi.

Pada tahapan persiapan, kegiatan Lapak Sedekah diawali dengan rapat koordinasi remaja dengan Ustadz Suroto dan Ustadzah Lilik Barkun Jamilah selaku pengasuh Madrasah Nur Rohim sekaligus penasihat komunitas. Pembahasan yang menjadi permasalahan awal yaitu terkait dengan bagaimana agar kegiatan ini diketahui oleh masyarakat terkait dengan sasaran donatur dan penerima donasi. Lalu munculah ide untuk dibuatkannya akun Facebook dan Instagram yakni Gerakan Sedekah Milenial. Lalu dibuatlah pamflet kegiatan untuk diunggah ke media sosial Whatsapp, Facebook dan Instagram baik akun milik komunitas maupun milik pribadi masing-masing. Pamflet tersebut sebagai bentuk ajakan dan sosialisasi kepada masyarakat yang ingin ikut berpartisipasi. Lalu waktu pengumpulan donasi dilaksanakan sekitar satu sampai dua minggu guna memaksimalkan pengadaan barang dan sembako sehingga dapat memenuhi kebutuhan masyarakat yang menerima donasi. Pengumpulan segala barang yang akan didonasikan bertempat di Madrasah Diniah Nur Rohim sebagai pusat kegiatan. Segala bentuk donasi diterima dengan baik dalam gerakan ini, bahkan untuk memudahkan bagi donatur yang tidak dapat mengantarkan donasinya ke tempat pengumpulan donasi, maka komunitas siap mengambil tentunya dengan pertimbangan jarak dan waktu. Selain itu, dengan melihat sasaran penyebaran pamflet di media sosial yang tentunya viewersnya tidak hanya masyarakat sekitar Tegalkamulyan, maka komunitas menyediakan rekening guna memudahkan transaksi bagi yang jaraknya jauh. Selama rentang waktu pengumpulan donasi itu pula dilakukan pensortiran berbagai barang yang telah didapatkan, yakni pemilihan pakaian yang masih layak pakai, pembelian sembako dan tetap terus mensosialisasikan dan membagikan pamflet di media sosial. 
Lalu pada tahapan persiapan, kegiatan ini disusun oleh anggota Gerak Sedekah Milenial sebagai pembawa acara, diawali dengan sambutan pembukaan oleh penasihat yakni ustadz Suroto, dilanjutkan dengan acara pengguntingan pita dan penerbangan balon udara oleh ustadzah Lilik Barkun Jamilah, dilanjutkan dengan pembacaan do'a bagi para donatur dan agar kegiatan lancar. Lalu dilanjutkan kegiatan inti yakni pembagian barang-barang hasil sedekah dari para donatur. Kegiatan ini tentunya dapat memberikan manfaat guna membangun kepedulian terhadap sesama.

Setelah itu di lanjut dengan tahapan evaluasi yakni dengan melihat serta menilai bagaimana keberlangsungan kegiatan tersebut. Apa yang sudah baik dalam kegiatan tersebut akan terus ditingkatkan, namun yang masih kurang tepat dalam kegiatan tersebut akan diperbaiki di Lapak Sedekah mendatang. Setiap pelaksanaan dijadikan pembelajaran bagi kesempurnaan dan keberhasilan Lapak Sedekah selanjutnya.

\section{HASIL DAN PEMBAHASAN}

Guna membangun kepedulian masyarakat pada sesama di masa pandemi Covid-19 di Desa Tegalkamulyan. Remaja desa di dampingi oleh para penasihat ustadz dan ustadzah madrasah diniah Nur Rohim melahirkan sebuah komunitas yang memiliki tujuan positif yakni Gerak Sedekah Milenial. Lalu dengan melihat latar belakang yang terjadi saat ini, permasalahan ekonomi yang menjadi permasalahan bagi sebagian besar masyarakat desa Tegalkamulyan yang terkena dampak kebijakan pemerintah guna memutus wabah pandemi, munculah sebuah kegiatan yang fokus pada bidang sosial yakni Lapak Sedekah.

Kegiatan Lapak Sedekah pertama kali dilakukan pada tanggal 8 Agustus 2021 dengan memperhatikan dan menggunakan protokol kesehatan. Selain dari anggota Gerak Sedekah Milenial, para ustadz dan ustadzah bahkan ketua pengasuh Madrasah Diniah Nur Rohim yakni Ustadz Suroto dan istrinya Ustadzah Lilik Barkun Jamilah ikut serta dalam kegiatan tersebut. Selain itu beberapa ibu-ibu sekitar juga ikut membantu dalam persiapan dan penyelenggaraan kegiatan ini. Yakni dengan pemajangan barang-barang donasi yang dapat diletakan di meja atau digantungkan. Serta dengan pengelompokan barang-barang donasi. Sasaran dari kegiatan Lapak Sedekah adalah warga sekitar yang membutuhkan bantuan. Kegiatan lapak sedekah dilakukan di depan sekretariat madrasah diniah Nur Rohim desa Tegalkamulyan. Lapak Sedekah ini menyediakan berbagai barang yang dibutuhkan oleh masyarakat. Berbagai barang yang didonasikan yang merupakan pemberian dari donatur dan sebagian dari lembaga. Adapun lokasi Lapak Sedekah dilaksanakan di depan Sekretariat Madrasah Diniah Nur Rohim, Perumahan Tegal Asri jalan Baruna Timur 4 RT 07 RW 16 Desa Tegalkamulyan, Kecamatan Cilacap Selatan, Kabupaten Cilacap, Provinsi Jawa Tengah.

Pada awal kegiatan Lapak Sedekah berlangsung, telah tersedia berbagai sembako dan barang yang diperoleh dari para donatur seperti al-Qur'an, beras, sembako, pakaian layak pakai, sepatu layak pakai, mie instan, daging ayam dan lain sebagainya. Tentunya semua sembako dan barang habis tak tersisa. Dengan melihat besarnya antusias warga tersebut, banyaknya mereka yang berdatangan dan mereka bahkan sampai berdesakan 
dapat diketahui realita betapa banyaknya mereka yang membutuhkan kepedulian dari masyarakat lain. Sosialisasi yang dilakukan oleh para anggota komunitas mendapatkan respon dan feedback yang baik dari masyarakat. Ditandai dengan keberhasilan pada awal peluncuran kegiatan ini. Dengan niat dan tujuan untuk menumbuhkan kepedulian membantu sesama yang membutuhkan di masa yang sulit ini, serta menjadi wadah dan penyalur bagi para donatur yang ingin membagikan sebagian hartanya. Jadi, konsep dari kegiatan ini adalah "Siapa saja boleh menaruh, dan siapa saja boleh mengambil".

Kegiatan Lapak Sedekah ini mampu menjawab permasalahan yang telah penulis sebutkan di atas yakni permasalahan ekonomi masyarakat dan permasalahan menurunnya sikap peduli pada remaja. Yakni dengan melihat antusias para remaja yang mampu menyukseskan kegiatan Lapak Sedekah dengan turut bergabung dan membantu kegiatan ini, serta antusias warga sekitar yang turut mendonasikan sebagian hartanya untuk dibagikan kepada yang membutuhkan, dan juga antusias warga penerima donasi. Selain itu kegiatan ini memberikan edukasi bagi remaja dan warga sekitar akan realita kehidupan masyarakat yang sedang dialami, sehingga dengan begitu dapat menumbuhkan sikap dan rasa peduli mereka dalam membantu terhadap sesama. Dengan aksi peduli yang remaja lakukan, maka dapat menanamkan karakter yang baik sehingga dapat menumbuhkan generasi yang berakhlak terpuji. Dengan pendampingan pemanfaatan teknologi dan media sosial yang tepat pula yakni sebagai ajang pensosialisasian kegiatan positif sehingga remaja dapat menggunakan teknologi dan media sosial tersebut secara bijak. Namun, dengan melihat antusias masyarakat penerima donasi yang membludak dan tak mau antri, pembagian yang tidak merata, pen gambilan barang atau sembako lebih dari dua sehingga yang datang siang tidak mendapatkan satu apapun. Tentunya dengan pengalaman kegiatan pada awal ini didapatkan dampak positif dan negatifnya, yang dapat dijadikan pelajaran untuk kegiatan Lapak Sedekah kedua dan bahkan seterusnya. Dampak positif yang didapatkan yakni menumbuhkan rasa peduli masyarakat terhadap sesama dan mengetahui kenyataan banyaknya masyarakat yang sangat membutuhkan kepedulian masyarakat lain, yang tentunya kegiatan ini mendapat respon yang positif oleh masyarakat. Namun dampak negatif yang didapatkan adalah timbulnya kerumunan dan desak-desakan yang diakibatkan membludaknya masyarakat.

Upaya yang dilakukan dalam rangka mengurangi dampak negatif yang ditimbulkan dari kegiatan tersebut, dengan tetap menjaga ketertiban dan protokol kesehatan, serta untuk mengantisipasi partisipasi dari warga, maka pada kegiatan yang akan dilaksanakan kedua kalinya, yakni tanggal 15 Agustus 2021, maka dilakukanlah rapat evaluasi dengan hasil:

1. Pemerataan pembagian sedekah dengan berkoordinasi melakukan pendataan warga yang berhak menerima sedekah bersama dengan ketua RT setempat

2. Pembuatan kupon yang digunakan untuk alat tukar barang atau sembako

3. Pembagian kupon sebelum hari kegiatan untuk warga yang terdata, melalui ketua RT yang sesuai dengan kebutuhannya

4. Pengadaan tempat yang lebih teratur dengan pembuatan penembatan barang ke pospos yang dibuat komunitas 
Kegiatan Lapak Sedekah diharapkan dapat terus berlanjut dan istiqomah baik saat pandemi maupun setelah berakhirnya wabah pandemi. Dan semoga kegiatan Lapak Sedekah dapat meluas tidak hanya di desa Tegalkamulyan tepatnya diperumahan Tegal Asri.

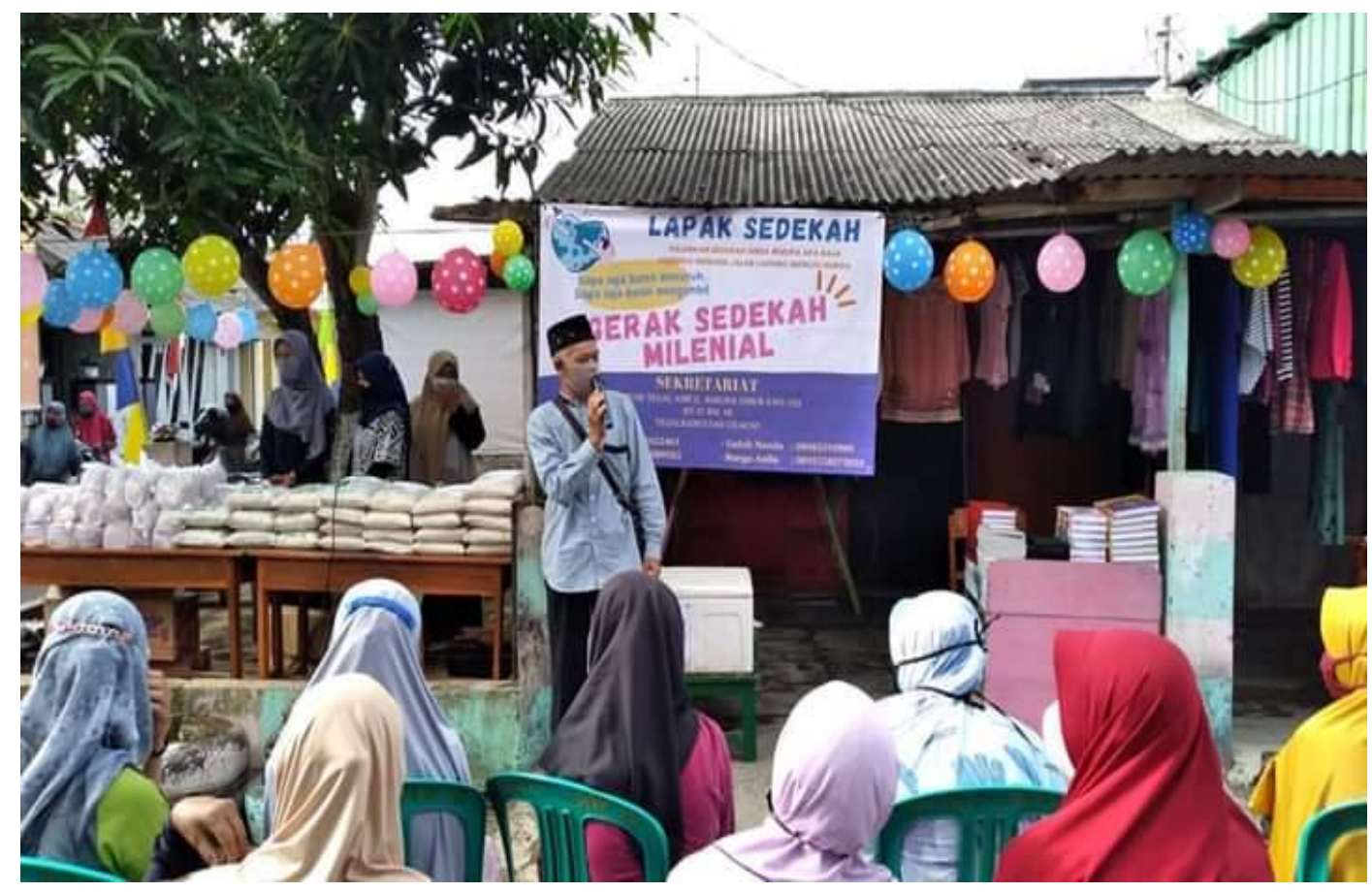

Gambar 1. Kegiatan Pembukaan Lapak Sedekah oleh penasihat Ustadz Suroto

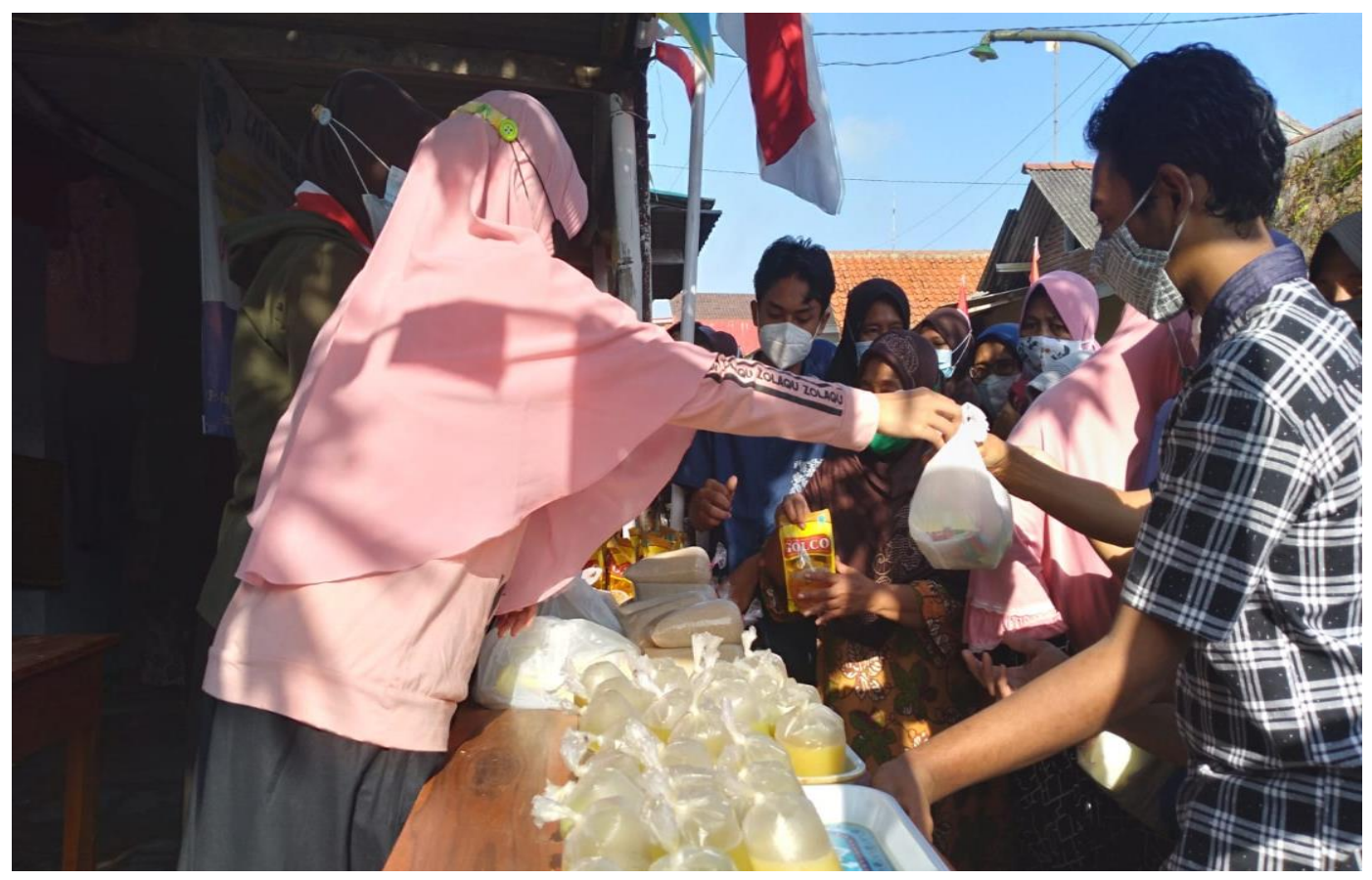

Gambar 2. Kegiatan Pembagian Donasi 


\section{KESIMPULAN}

Komunitas Gerak Sedekah Millennial yang berupaya dalam membangun kepedulian pada sesama di masa pandemi Covid-19 di Desa Tegalkamulyan tepatnya di perumahan Tegal Asri sehingga melahirkan gerakan yang fokus di bidang sosial yaitu Lapak Sedekah, Kegiatan mampu memberikan kesan yang positif yang tentunya dapat membangun rasa peduli mereka mulai dari generasi tua maupun generasi muda. Kegiatan ini dapat memberikan pembelajaran bagi sebagian masyarakat dan sekaligus menjadi wadah kemanusiaan dan kesejahteraan sosial bagi pihak donatur dan pihak penerima donasi. Kegiatan Lapak Sedekah menjadi ajang edukasi generasi muda untuk lebih terbuka dengan peduli terhadap realita kehidupan di sekitar.

\section{UCAPAN TERIMAKASIH}

Terima kasih kepada Ustadz Suroto dan Ustadzah Lilik Barkun Jamilah selaku pengasuh Madrasah Diniah Nur Rohim sekaligus penasihat komunitas Gerak Millennial Sedekah, Dosen Pembimbing Lapangan bapak Lutfhi Faishol, M.A, teman-teman KKNMB angkatan 48 IAIN Purwokerto, Ustadz dan Ustadzah Madrasah Diniah Nur Rohim, anggota komunitas Gerak Sedekah Milenial, panitia Lapak Sedekah, serta masyarakat setempat atas antusias nya dalam menyukseskan acara Lapak Sedekah baik sebagai donatur maupun penerima donasi.

\section{DAFTAR PUSTAKA}

Adelia, D., Hildayani, H., \& Marimbun, M. (2021). Meningkatkan pemahaman pola hidup sehat melalui penyuluhan di Gampong Sungai Pauh. Connection: Jurnal Pengabdian Kepada Masyarakat, 1(1), 14-21.

Basar, Afip Miftahul. (2021). Problematika Pembelajaran Jarak Jauh Pada Masa Pandemi Covid-19 (Studi Kasus di SMPIT Nurul Fajri-Cikarang Barat-Bekasi). Jurnal Ilmiah Pendidikan. Vol. 2. No. 1.

Effendi, Rahayu, dkk. (2018). Pemahaman Tentang Lingkungan Berkelanjutan. Jurnal Modul. Vol. 18. No. 2.

Hidayah, Nurul, dkk. (2021). Gambaran Pengetahuan Masyarakat Tentang Pencegahan Covid-19 di Kecamatan Padangsidimpuan Batunadua, Kota Padangsidampuan. Jurnal Kesehatan Ilmiah Indonesia. Vol. 6. No. 1.

Indraddin dan Irwan. (2016). Strategi dan Perubahan Sosial. Yogyakarta: Deepublish.

Kertajaya, Hermawan. (2008). Arti Komunitas. Jakarta: Gramedia Pustaka Utama.

Marimbun, M. (2021). Meningkatkan Aspirasi Karier di Sekolah Melalui Layanan Bimbingan dan Konseling. Jurnal Wahana Konseling, 4(1), 1-12.

Mungkasa, Oswar. (2020). Bekerja dari Rumah (Working From Home/WFH): Menuju Tatanan Baru Era Pandemi Covid-19. Jurnal Of Development Planning. Vol. IV. No. 2. 
Salasiah, dkk. (2020). Membangun Kepedulian Pada Sesama di Masa COVID-19. Jurnal Pelayanan Kepada Masyarakat. Vol. 2. No. 2.

Setiawan, M. Aulia. (2017). Penerapan Model Analisis Dilema Moral Terhadap Sikap Peduli Sosial Siswa Pada Kompetensi Dasar Menampilkan Sikap Positif Berpancasila Dalam Kehidupan Bermasyarakat. Jurnal Penelitian Pendidikan. Vol. 20. No. 1.

Soekanto, Soerjono. (2000). Sosiologi Suatu Pengantar. Jakarta: PT. Raja Grafindo Persada.

Triyana, V., \& Marimbun, M. (2021). Meningkatkan ketahanan pangan bidang pertanian melalui budidaya tanaman sayur sayuran. Connection: Jurnal Pengabdian Kepada Masyarakat, 1(1), 1-6.

Worldometers. (2021. 19 September). Covid-19 Coronavirus Pandemic. (https://www.worldmeters.info/coronavirus/ )

Youharti, Inta Elok dan Hidayah. (2018). Perilaku Phubbing Sebagai Karakter Remaja Denerasi Z. Jurnal Fokus Konseling. Vol. 10. No. 1.

Zulkipli dan Muharir. (2021). Dampak Covid-19 Terhadap Perekonomian Indonesia. Jurnal Ilmiah Mahasiswa Ekonomi Syariah. Vol. 1. No. 1. 